presentes todos os professores e muitos amigos e admiradores do professor Spencer Vampré.

Aberta a sessão pelo profesor Sampáio Dória. vice-diretor em exercicio, foram designados os professores Vicente Ráo e Jorge Americano para acompanhar á sala o novo diretor. Lida a ata de posse, o professor Sampáio Doria congratulou-se com a Faculdade de Direito pela escolha do ilustre mestre.

Em nome da congregação falou o professor Alcantara Machado, saudando o professor Spencer Vampré.

Assumindo o cargo, o novo diretor principiou por agradecer as referências á sua pessoa e aludiu ás responsabilidades do posto que acabava de lhe ser conferido. Disse que contava com o valioso auxilio de todos os seus ilustres colegas para uma brilhante orientação da Faculdade de Direito e para cujo progresso, sempre e cada vez mais crescente, dava em penhor o seu coração e o melhor da sua inteligência, afim de que, dessa forma, a obra empreendida fosse mais por amor do Brasil e de São Paulo.

\title{
HOMENAGEM DAS ENTIDADES ACADEMICAS AO PROFESSOR FRANCISCO MORATO
}

Patrocinada pelas entidades acadêmicas Academia de Letras da Faculdade de Direito, Associação Acadêmica "Alvares de Azevedo", Campanha Pró-Monumento aos Bandeirantes, Centro Jurídico "Glovis Bevilaqua", Partido Acadêmico Conservador e Sociedade dos Acadêmicos Amigos da Itália, foi prestada, no dia 31 de maio, na sala "João Mendes Junior", homenagem ao professor Francisco Morato, com numerosa assistência.

A homenagem foi o testemunho de apreço e reconhecimento da mocidade acadêmica de São Paulo á atuação do professor Morato, como diretor da Faculdade de Direito.

\section{COMEMORAÇÃO DA INDEPENDÊNCIA ARGENTINA NA FACULDADE DE DIREITO}

Com a presença do sr. Consul Argentino, da mocidade acedêmica e mais pessoas gradas, realizou-se, a 25 de maio, na sala "João Mendes Junior", a comemoração da data da independência da República Argentina, solenidade presidida pelo professor Spencer Vampré, di- 